\title{
Increasing the tolerance to copper of ornamental plants and lawn grasses in urban ecosystems
}

\author{
Evgeny Aleksandrovich GLADKOV ${ }^{*}$, Ilina Igorevna TASHLIEVA ${ }^{1}$, Yuliya Ivanovna DoLGIKH ${ }^{1}$, \\ Olga Victorovna GLADKOVA ${ }^{2}$ \\ Manuscript received on March 4, 2021 and accepted on June 25, 2021 \\ ${ }^{1}$ K.A. Timiryazev Institute of Plant Physiology RAS, IPP RAS, 35 Botanicheskaya St., \\ Moscow, 127276 Russia \\ ${ }^{2}$ Independent scientist, Moscow, Prospekt Mira, 181, Russia
}

\begin{abstract}
The plants are an important part of the urban ecosystem. Plants help to reduce the level of pollution and the effect of adverse environmental factors on urban ecosystems. Among the most dangerous pollutants for plants are copper ions. Copper is one of the main pollutants of urban soil. Copper ions significantly reduce the quality of ornamental plants. One approach to solve this problem is to create plants resistant to adverse environmental factors using cell selection. This method is hardly ever used in urban greening. The aim of the work is to produce plants resistant to copper ions. It was developed technologies to obtain ornamental plants resistant to copper. These plants have substantially increased their resistance to copper. Plants Festuca rubra were resistant to high levels of copper contamination and can grow on the basis of the level of pollution along roads, in residential areas. Plants Brachycome iberidifolia proved to be resistant to the average level of pollution of copper and can grow in parks and squares.
\end{abstract}

Keywords: urban greening, ornamental plants, urban ecosystem, copper, Brachycome iberidifolia, Festuca rubra

\section{Introduction}

The plants are an important part of the urban ecosystem. Urban greening contributes notably to quality of life and ecosystem services in cities [1]. Plants help to reduce the level of pollution and the effect of adverse environmental factors on urban ecosystems. Condition and quality of the lawn grass and flowering plants are important indicators of the level of landscaping and the urban environment. Purpose and environmental conditions determine the choice of plants for the lawn. Festuca rubra L. forms lawn of the highest quality. The structure of meadow grasses flowering plants include for example, Brachycome iberidifolia Benth., Linum grandiflorum L., Chrysanthemum carinatum L. etc.. Brachycome iberidifolia is a spectacular ornamental plant

\footnotetext{
*corresponding author, E-mail: gladkovu@mail.ru
} 
and is used for decoration of the flower beds. Unfortunately the previously plants, like the majority of other ornamental plants are very sensitive to pollution of urban soil. Among the most dangerous pollutants for plants is ions copper. Copper has the highest phytotoxicity among the common heavy metals [2].

The standard copper content is $17 \mathrm{mg} / \mathrm{l}$ in the world's soils [3]. The background content of copper in the soils of the Moscow region is $15 \mathrm{mg} / \mathrm{l}$. Copper is one of the main pollutants of urban soil [4-8]. In some areas in Moscow there is an excess of approximate permissible concentration, which is $132 \mathrm{mg} / \mathrm{kg} \mathrm{Cu}$. The average copper contents in Moscow was $33.5 \mathrm{mg} / \mathrm{kg}$ [9]. Total $\mathrm{Cu}$ concentrations were elevated 5-27 times in the urban soils of Copenhagen compared to an agricultural reference soil [10].

Soil $\mathrm{Cu}$ contents increased in the following order: non-urban < green-urban < peri-urban < urban soils [11]. Traffic is believed to be one of the main sources of $\mathrm{Cu}$ in urban soil [11,12]. $\mathrm{Cu}$ accumulation in urban soils, resulting from urbanization, may generally influence denitrification in urban ecosystems [13]. Copper ions significantly reduce the quality of ornamental plants. Copper ions have strong influence on development and growth of plants [14]. Thus the copper limits the use of many ornamental plants. Damaged landscape can be restored with the help of biotechnology. One approach to solve this problem is to create plants resistant to adverse environmental factors using cell selection $[15,16]$. This method is rarely used in urban landscaping. To use cell selection, it is necessary to introduce plants into a cell culture, for some ornamental plant species this technology is very laborious $[7,8,17,18]$. The aim of the work is to produce ornamental plants resistant to copper ions.

\section{Materials and methods}

Festuca rubra L. is perennial bunchgrass. It is found in many natural green areas on nearly all types of soils. Red fescue can grow between 2 to $20 \mathrm{~cm}$ tall. It thrives under a wide range of conditions and is resistant to dry poor soil, frost and drought.

Brachycome iberidifolia Benth. is an annual herb, Asteraceae. The leaves of Brachyscome iberidifolia are fully divided, each having long and narrow segments from the midrib. The ray florets are varied in color, white through pink and blue to violet. Brachycome iberidifolia is used for decoration of the meadow grasses, flower beds, curbs, rocky hills. 


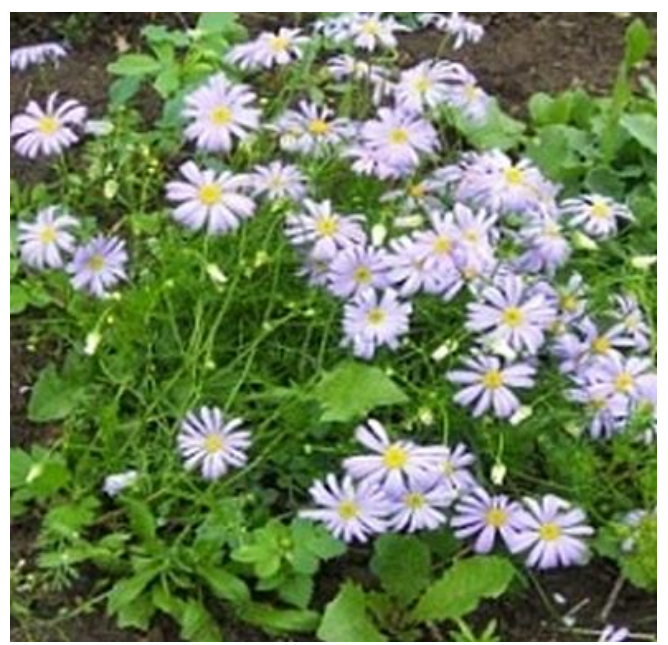

Figure 1. Brachycome iberidifolia

For getting callus we used seeds. Seeds were sterilized by soaking for $1 \mathrm{~min}$. with $70 \%$ ethanol, then agitated in $2.6 \%$ sodium hypochlorite, followed by three times rinses in sterile water. The cultures incubated at $26^{\circ} \mathrm{C}$ were exposed to a $16-\mathrm{h}$ photoperiod. Sterile seeds were placed in Petri dishes in the light and humidity $70 \%$.

Surface-sterilized explants of Festuca rubra were inoculated on to Murashige and Skoog (MS) medium supplemented with $3 \mathrm{mg} / 1$ 2,4-diclorophenoxiacetic acid (2,4-D), 3\% sucrose, $0.05 \%$ $\mathrm{mg} / \mathrm{l}$ caseinhydrolysat, $0.7 \%$ agar-agar. Then callus were transferred to MS medium containing $1 \mathrm{mg} / \mathrm{l}$ 2,4-D. Regenerated shoots were cultured on MS medium without hormones, for root induction was used MS medium supplement with $2 \mathrm{mg} / \mathrm{l}$ naphthalenacetic acid (NAA).

For induction callus of Brachycome iberidifolia was used Gambourg medium supplement with $3 \%$ sucrose, with $2 \mathrm{mg} / \mathrm{l}$ 2,4-D and $2 \mathrm{mg} / \mathrm{l}$ kinetin. Then embryo callus were transferred to 1/2MS medium supplement with $1.5 \%$ sucrose, $2 \mathrm{mg} / 1$ 6-benzylaminopurine (BAP) and $0.1 \mathrm{mg} / \mathrm{l}$ NAA. Studies have shown that the concentration of $2 \mathrm{mg} / \mathrm{l} \mathrm{BAP}$ increased the level of formation of regenerants then the previously used concentration of $1 \mathrm{mg} / \mathrm{l} \mathrm{BAP}$. For root induction was used 1/2MS medium supplement with $0.1 \mathrm{mg} / 1$ NAA [17,19].

To select tolerant plants of Festuca rubra and Brachycome iberidifolia was work out the methods selection. Callus of Festuca rubra were cultured on MS medium with addition 150 $\mathrm{mg} / \mathrm{l} \mathrm{CuSO}{ }_{4} 5 \mathrm{H}_{2} \mathrm{O}$. After culturing for 1 month, increase in size, light callus were collected. Then callus are transplanted on regeneration and rooting medium supplemented with copper at a concentration of $150 \mathrm{mg} / \mathrm{l}$.

Selection scheme of Brachycome iberidifolia consisted of culturing the callus on Gambourg medium with $20 \mathrm{mg} / 1 \mathrm{CuSO}_{4} .5 \mathrm{H}_{2} \mathrm{O}$ during 26 days and then induction shoot and root on the medium without copper.

The standard deviation was calculated using Microsoft Office Excel 2003. 


\section{Results and discussion}

The copper concentration of $150 \mathrm{mg} / \mathrm{l}$ was chosen as selective concentration for tissue Festuca rubra. [19]. Scheme of selection Festuca rubra consist of culturing a callus for 1-2 subcultured on modified MS medium supplemented with $150 \mathrm{mg} / \mathrm{l}$ of copper, regeneration on MS medium supplemented with $150 \mathrm{mg} / \mathrm{l}$ of copper and rooting of plants on MS medium with $150 \mathrm{mg} / \mathrm{l}$ of copper. All received 10 regenerated plants (Table 1). Most obtained regenerants possessed increased resistance to $150 \mathrm{mg} / \mathrm{kg}$ of copper.

Table 1. Selection of tolerance Festuca rubra to copper ions.

\begin{tabular}{|c|c|c|c|}
\hline $\begin{array}{c}\text { Total number } \\
\text { of callus }\end{array}$ & $\begin{array}{c}\text { Number of resistant } \\
\text { clones }\end{array}$ & $\begin{array}{c}\text { Number of regenerants } \\
\text { in vitro }\end{array}$ & $\begin{array}{c}\text { Number of } \\
\text { regenerated in the soil }\end{array}$ \\
\hline 750 & 184 & 32 & 10 \\
\hline
\end{tabular}

Callus of Brachycome iberidifolia were much more sensitive to copper than tissue of Festuca rubra. It was previously shown that callus of Brachycome iberidifolia were tolerant to $10 \mathrm{mg} / \mathrm{l}$ of copper [17], but at the concentration of $30 \mathrm{mg} / \mathrm{l} \mathrm{copper} \mathrm{toxic} \mathrm{effect} \mathrm{was} \mathrm{increased} \mathrm{(Figure} \mathrm{2).}$

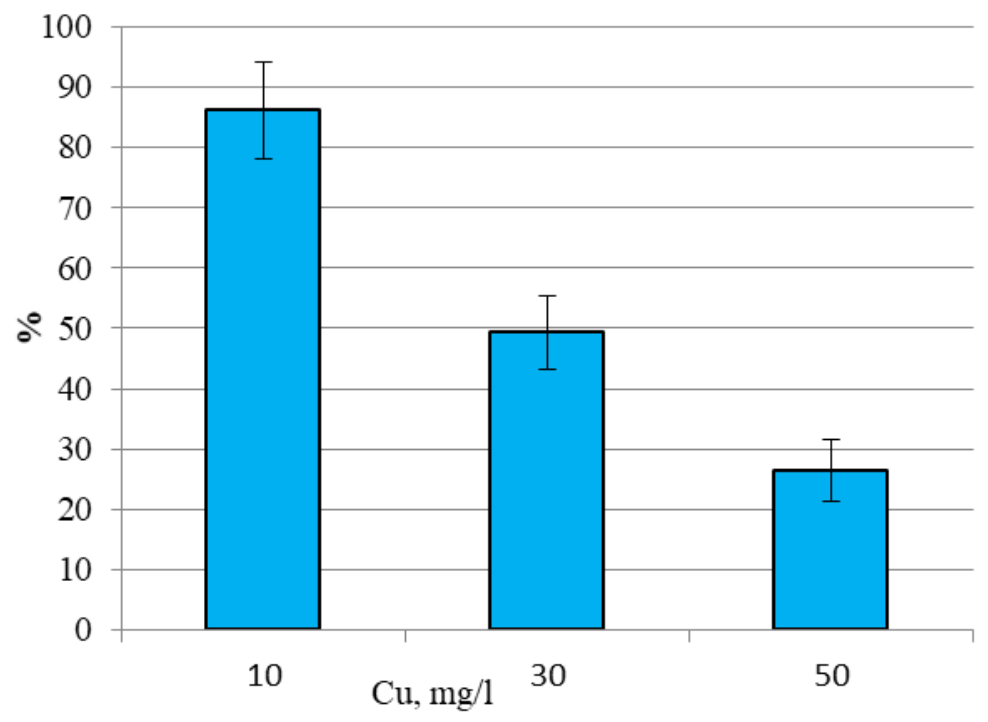

Figure 2. Effect of copper on the survival of calli of Brachycome iberidifolia in 1 passage

Therefore, it was necessary to modify the approach for obtaining plants resistant to copper. For resistant plant Brachycome iberidifolia was chosen the scheme selection without toxicant during regeneration and rooting stages. The cell selection scheme: callus was transferred on Gambourg medium supplement with $2 \mathrm{mg} / \mathrm{l}$ 2,4-D and $2 \mathrm{mg} / \mathrm{l}$ kinetin and $20 \mathrm{mg} / \mathrm{l} \mathrm{Cu}$ and cultivated with subculturing for 26 days, regeneration with 3-4 times subculturing on $1 / 2 \mathrm{MS}$ 
medium and supplemented with $2 \mathrm{mg} / \mathrm{l} \mathrm{BAP}$ and $0.1 \mathrm{mg} / \mathrm{l} \mathrm{NAA}$, rooting on $1 / 2 \mathrm{MS}$ medium with $0.1 \mathrm{mg} / \mathrm{l}$ NAA without toxicant.

As a result of the selection were received plants of Brachycome iberidifolia.

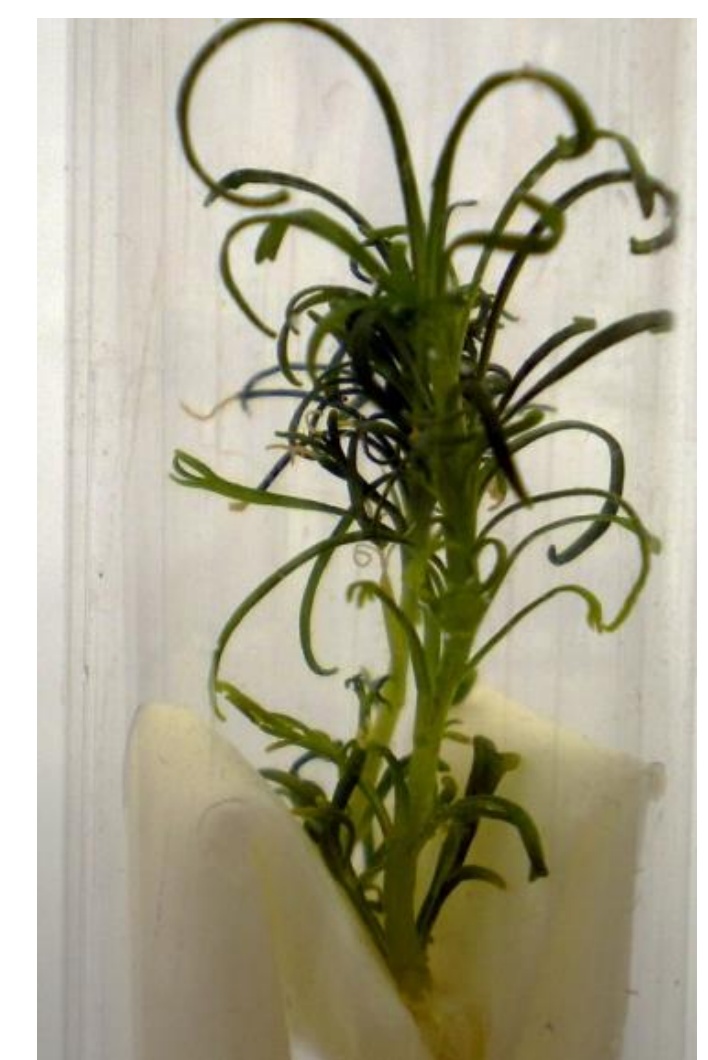

Figure 3. Brachycome iberidifolia regenerants after cell selection

Most obtained regenerants possessed increased resistance to $20 \mathrm{mg} / \mathrm{l}$ of copper. All regenerants remained viable, in contrast to the controls plant. At a concentration of $20 \mathrm{mg} / \mathrm{l}$ after 30 days resistant clones have $100 \%$ survival of shoots and the control plants survive $43 \%$. 


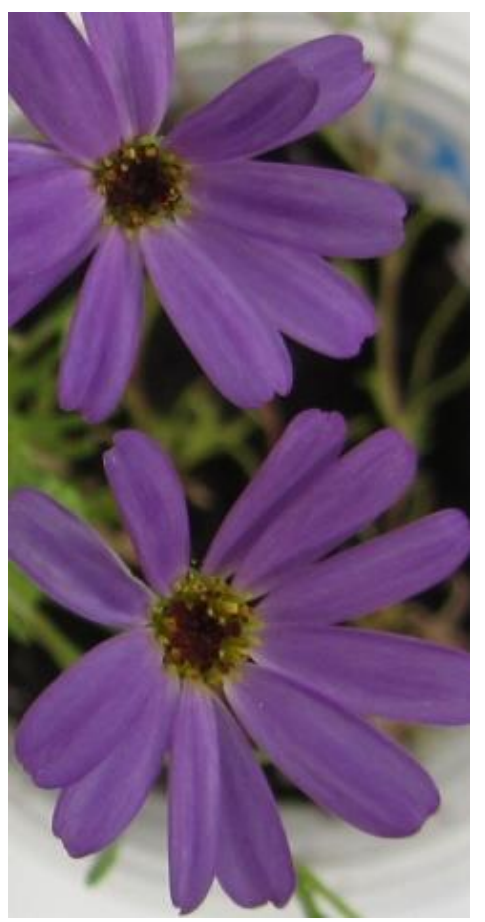

Figure 4. Brachycome iberidifolia regenerants after cell selection

All regenerants retained high decorative qualities in the soil under control conditions. Some regenerants bloomed at copper concentrations 20 and $30 \mathrm{mg} / \mathrm{kg}$ (Figure 4). No flowering was observed in the original plants. Most obtained regenerants possessed increased resistance to 20 and $30 \mathrm{mg} / \mathrm{kg}$ of copper.

\section{Conclusions}

Thus, we developed technologies to obtain plants resistant to copper. Work on obtaining ornamental plants that are resistant to copper is rare. Only plants of Chrysanthemum carinatum and Agrostis stolonifera obtained [18]. For obtaining resistant plants Festuca rubra were used the mediums supplemented with copper sulfate in each step, including the regeneration and rooting. For obtaining resistant plants Brachycome iberidifolia was used the medium supplemented with copper sulfate only at the stage of cultivation callus.

These plants have substantially increased their resistance to copper. Plants Festuca rubra were resistant to high levels of copper contamination and can grow on the basis of the level of pollution along roads, in residential areas. Brachycome iberidifolia proved to be resistant to the average level of pollution of copper and can grow in parks and squares. 
Bulletin de la Société Royale des Sciences de Liège, Vol. 90, Articles, 2021, pp. 181-188

\section{Comment}

Part of the work was done at the Department of ecological and industrial biotechnology, Moscow State University of Mechanical Engineering (earlier Moscow State University of Environmental Engineering), which is currently reorganized.

\section{References}

[1] Jim, C.Y. (2013). Sustainable urban greening strategies for compact cities in developing and developed economies. Urban Ecosyst, 16, 741-761. https://doi.org/10.1007/s11252-012$\underline{0268-\mathrm{x}}$

[2] Guralchuk Zh. Z. (1994). Mechanisms of Plant Resistance to Heavy Metals. Physiology and Biochemistry of Cultivated Plants 26, 2:107-118.

[3] Volgin D.A. (2011) Background level and content of heavy metals in the soil cover of the Moscow region. Bulletin of the Moscow State Regional University (Electronic journal). Section "Geography" No. 1. p. 26-33.

[4] State report "On the state and Environmental Protection of the Russian Federation in 2010". (2011) Moscow, Ministry of Natural Resources and Environment of the Russian Federation.

[5] Report on environment condition of Moscow city in 2017 (2018). Moscow Department for Environmental Management and Protection.

[6] Report on environment condition of Moscow city in 2018 (2019). Moscow Department for Environmental Management and Protection.

[7] Gladkov E.A. \& Gladkova O.V. (2018) Ecology and ecological and biotechnological aspects of the use of phytotechnologies. Monograph. Moscow, Internauka, 102 p. ISBN 9785-9500175-9-9

[8] Gladkov E.A. \& Gladkova O.V. (2018) Ecology. Moscow, Internauka, 104 p. ISBN 9785-6042527-0-3

[9] Report on environment condition of Moscow city in 2011 (2012) Moscow Department for Environmental Management and Protection.

[10] Li L.J., Holm P.E., Marcussen H., Bruun Hansen H.C. (2014). Release of cadmium, copper and lead from urban soils of Copenhagen. Environmental Pollution, 187, 90-97, https://doi.org/10.1016/j.envpol.2013.12.016.

[11] Nannoni F., Rossi S., Protano G. (2014). Soil properties and metal accumulation by earthworms in the Siena urban area (Italy). Applied Soil Ecology, 77, 9-17.

https://doi.org/10.1016/j.apsoil.2014.01.004 
Bulletin de la Société Royale des Sciences de Liège, Vol. 90, Articles, 2021, pp. 181-188

[12] Yang J.L. \& Zhang G.L. (2015) Formation, characteristics and eco-environmental implications of urban soils - A review, Soil Science and Plant Nutrition, 61:sup1, 30-46, https://doi.org/10.1080/00380768.2015.1035622

[13] Li, S., Yang, X., Buchner, D., Wang, H., Xu, H., Haderlein, S., \& Zhu, Y. (2018). Increased copper levels inhibit denitrification in urban soils. Earth and Environmental Science Transactions of the Royal Society of Edinburgh, 109(3-4), 421-427.

https://doi.org/10.1017/S1755691018000592

[14] Manivasagaperumal, R., Vijayarengan, P., Balamurugan, S., Thiyagarajan, G. (2011) Effect of copper on growth, dry matter yield and nutrient content of Vigna radiata (L) Wilczek. J Phytol, 3:53-62

[15] Gori, P., Schiff, S. (1998). Response of in vitro Cultures of Nicotiana Tabacum L to copper stress and selection of plants from $\mathrm{Cu}$ - tolerant callus. Plant cell tissue and organ culture, 53(3), 161-169. https://doi.org/10.1023/A:1006048031956

[16] Gladkov, E.A., Dolgikh, Yu.I., Gladkova, O.V. (2014) In vitro selection for tolerance to soil chloride salinization in perennial grasses. Sel'skokhozyaistvennaya Biologiya (Agricultural Biology), nº 4, 106-111.

[17] Gladkov, E.A., Tashlieva, I.I., Dolgikh, Y.I., Gladkova O.V. (2019) Increasing Tolerance Agrostis Stolonifera, Festuca Rubra, Brachycome Iberidifolia, Chrysanthemum Carinatum to Copper. In: Cárdenas R., Mochalov V., Parra O., Martin O. (eds) Proceedings of the 2nd International Conference on BioGeoSciences, BG 2017. Springer, Cham, 167-174. DOI https://doi.org/10.1007/978-3-030-04233-2_15

[18] Gladkov, E.A., Tashlieva, I.I., Gladkova, O.V.(2020) Ornamental plants adapted to urban ecosystem pollution: lawn grasses and painted daisy tolerating copper. Environmental Science and Pollution Research. https://doi.org/10.1007/s11356-020-11423-6.

[19] Litvinova, I.I., Gladkov, E.A., Dolgikh, Y.I., Gladkova O.V. (2016). Increased resistance Brachycome Iberidifolia and Festuca Rubra to soil copper ions. Izvestia of Samara scientific center of the Russian academy of sciences,18(5),160-162. 